\title{
AN OVERVIEW OF MEDICINAL VALUE OF CURCUMA SPECIES
}

\author{
VANITA KANASE*, FARHA KHAN
}

Department of Pharmacology, Oriental College of Pharmacy, Sanpada, Navi Mumbai - 400 705, Maharashtra, India. Email: vanita.kanase@gmail.com

Received: 27 June 2018, Revised and Accepted: 02 August 2018

\section{ABSTRACT}

Curcuma is a genus of about 100 accepted species in the family Zingiberaceae that contains such species as turmeric and Siam tulip. They are native to Southeast Asia, southern China, ISSN (Online): 2319-7064 ISSN (Online): 2319-7064 naturalized in other warm parts of the world such as Tropical Africa, Central America, Florida, and various islands of the Pacific, Indian, and Atlantic Oceans. Few known species of Curcuma with reported pharmacological activity are Curcuma longa, Curcuma aeruginosa, Curcuma pseudomontana, Curcuma aromatica, Curcuma xanthorrhiza, Curcuma zedoaria, Curcuma angustifolia. Among them, $C$. longa is the one species extensively studied and has ancient traditional medicinal uses. These Curcuma species have been used in traditional medicine as a household remedy for various diseases, including biliary disorders, anorexia, cough, diabetic wounds, hepatic disorders, rheumatism, and sinusitis. For the past few decades, extensive work has been done to establish the biological activities and pharmacological actions of Curcuma species and its extracts. This review article is created with an intention to give an overview on the reported research carried out on the Curcuma species such as anticancer activity, antitumor, antitubercular, antibacterial, antimicrobial, toxicity activity, and wound healing. And also, these Curcuma species can be considered as herbal medicinal plant having a plethora of research opportunities based on its traditional use and biological activity.

Keywords: Curcumin, Curcuma longa, Anticancer, Antibacterial, Traditional use, Pharmacological activity.

(c) 2018 The Authors. Published by Innovare Academic Sciences Pvt Ltd. This is an open access article under the CC BY license (http://creativecommons. org/licenses/by/4. 0/) DOI: http://dx.doi.org/10.22159/ajpcr.2018.v11i12.28145

\section{INTRODUCTION}

Although modern medicine has been routinely used in the treatment of various diseases, it is $<100$ years old. The genus was first established by Carl Linnaeus in 1753. The name Curcuma is derived from the Arabic word kurkum, meaning "yellow," which refers to the color of the rhizome. Traditional medicine, in comparison, has served mankind for thousands of years and is quite safe and effective. The mechanism or the scientific basis of traditional medicine, however, is less well understood. Throughout the Orient, Curcuma species is traditionally used for both prevention and therapy of diseases. Modern in vitro studies reveal that Curcuma species is a potent antioxidant, antiinflammatory, antimicrobial, and anticancer agent [1]. India is popularly known as the "Spice Bowl of the World" as a wide variety of spices with premium quality is grown in the country since ancient times. However, among all those ancient spices, one which is virtually associated and intertwined with all individuals in issues related to food as well as life, so far as aroma, taste, flavor, color, society, religion, economy, ecology, and emotion is concerned, which is turmeric. Turmeric not only adds golden grace but also considered as the golden spice and grown almost all over the world, especially in India, Bangladesh, Burma, China, Indonesia, Myanmar, Nigeria, Pakistan, Sri Lanka, Taiwan, etc. Among these countries, India occupies the first position in area $(2,22,000 \mathrm{ha})$ and in production $(11,32,000 \mathrm{MT})$. Extensively cultivated in Southeast Asia specifically Bengal, China, Taiwan, Sri Lanka, Indonesia. Among these compounds, curcumin, which is mainly found in Curcuma longa, is the most widely investigated. In the past several decades, this compound has been studied in numerous comprehensive reviews examining its structure, synthesis, derivatives, and biological activities. Many species of the genus Curcuma caesia, Curcuma rubescens, Curcuma amada, Curcuma leucorrhiza, Curcuma montana, Curcuma aromatica, Curcuma zedoaria, Curcuma angustifolia, Curcuma pseudomontana, C. longa, etc. are there with huge diversity and enormous medicinal usage [2]. Table 1 gives the list of all the Curcuma species along with their pharmacological activity enlisted in this article.

\section{CURCUMA AERUGINOSA}

C. aeruginosa is a perennial plant producing unbranched leafy stems up to $200 \mathrm{~cm}$ tall from a large underground rhizome that can be $16 \mathrm{~cm}$ long and $3 \mathrm{~cm}$ wide [3]. The inflorescence develops from the rhizome, usually before the leaves are produced. The plant is gathered from the wild for use in traditional medicine and as a food. It is often grown in Malaysia as a medicinal plant and is also sometimes cultivated as an ornamental [4].

\section{Pharmacological activity}

Antimicrobial activity

Kamazer et al. cycloisolongifolene, 8, 9-dehydro formyl (35.29\%) and dihydrocostunolide $(22.51 \%)$ were the major compounds in C. aeruginosa oil; essential oils obtained by steam distillation were analyzed by gas chromatography-mass spectrometry (MS). The antimicrobial activity of the essential oils was evaluated against four bacteria: Bacillus cereus, Staphylococcus aureus, Escherichia coli, and Pseudomonas aeruginosa [5].

The preliminary results suggest promising antimicrobial properties of C. aeruginosa, which may be useful for food preservation, pharmaceutical treatment, and natural therapies.

\section{Anti-inflammatory activity}

Asihtriauti et al. in their present study evaluated the anti-inflammatory activity of $C$. aeruginosa ethanolic extracts in experimental animals. The topical anti-inflammatory activity was analyzed using croton oil-induced ear edema. Topical application of (Curcuma aeruginosa ethanolic extracts (80 mg/ear, $160 \mathrm{mg} /$ ear) reduced ear edema and pro-inflammatory cells (histological analysis) in the tissue and its activity was similar to hydrocortisone $1 \%(\mathrm{p}>0.05)$. The ethanolic extract showed strong anti-inflammatory activity [6]

\section{AMADA}

Mango ginger (C. amada Roxb.) is a unique spice having morphological resemblance with ginger but imparts a raw mango flavor. The main use 
Table 1: The list of all the Curcuma species along with their pharmacological activity enlisted in this article

\begin{tabular}{|c|c|}
\hline Curcuma species & Pharmacological activity \\
\hline \multirow[t]{2}{*}{ Curcuma aeruginosa } & Antimicrobial[5] \\
\hline & Anti-inflammatory [6] \\
\hline \multirow[t]{3}{*}{ Curcuma amada } & Antioxidant[9] \\
\hline & Anti-inflammatory[8] \\
\hline & Antitubercular [10] \\
\hline Curcuma angustifolia & Anti-ulcerogenic [12] \\
\hline \multirow[t]{4}{*}{ Curcuma aromatica } & Wound healing[14] \\
\hline & Anticancer [13,15-17] \\
\hline & Antioxidant $[20,21]$ \\
\hline & Larvicidal $[13,18,19]$ \\
\hline \multirow[t]{2}{*}{ Curcuma caesia } & Smooth muscle relaxant[22] \\
\hline & Scavenging/antioxidant [23] \\
\hline \multirow[t]{3}{*}{ Curcuma longa } & Anticancer[30] \\
\hline & Antimalarial[31] \\
\hline & Anticoagulant $[32,33]$ \\
\hline \multirow[t]{3}{*}{ Curcuma pseudomontana } & Antimicrobial[36] \\
\hline & Antitubercular[37] \\
\hline & Anticancer [38] \\
\hline \multirow[t]{3}{*}{ Curcuma xanthorrhiza } & Cytotoxicity activity[47] \\
\hline & Hepatoprotective[48] \\
\hline & Anti-inflammatory [49] \\
\hline \multirow[t]{6}{*}{ Curcuma zedoaria } & Antitumor[66] \\
\hline & Antibacterial/antimicrobial[58] \\
\hline & Anti-amoebic activity[69] \\
\hline & Anticancer activity $[60,67,68]$ \\
\hline & Hepatoprotective activity [70-72] \\
\hline & Antivenom activity [73] \\
\hline
\end{tabular}

of mango ginger rhizome is in the manufacture of pickles and culinary preparations. Ayurveda and Unani medicinal systems have given much importance to mango ginger as an appetizer, alexiteric, antipyretic, aphrodisiac, diuretic, emollient, expectorant, and laxative and to cure biliousness, itching, skin diseases, bronchitis, asthma, hiccough, and inflammation due to injuries. The biological activities of mango ginger include antioxidant activity, antibacterial activity, antifungal activity, anti-inflammatory activity, platelet aggregation inhibitory activity, cytotoxicity, anti-allergic activity, hypotriglyceridemic activity, brine shrimp lethal activity, enterokinase inhibitory activity, central nervous system depressant, and analgesic activity. The major chemical components include starch, phenolic acids, volatile oils, curcuminoids, and terpenoids suchs difurocumenonol, amadannulen, and amadaldehyde [7].

\section{Pharmacological activity}

Anti-inflammatory activity

Ethanol extract of $C$. amada showed the presence of multiple chemical constituents with the presence of hydroxyl, ester, carbonyl, and olefinic groups. The extract showed dose-dependent anti-inflammatory activity, which was found to be statistically significant at higher concentration in acute carrageenan-induced rat paw edema model. That extract shows anti-inflammatory activity at various acute phases of inflammation and on the formation of granular tissue [8].

\section{Antioxidant activity}

Policegoudra et al. stated that chloroform extract of mango ginger (C. amada Roxb.) rhizome was subjected to antioxidant activity-guided decontamination by repeated silica gel column chromatography to obtain a pure form of the antioxidant compound. The structure was inferred by analyzing UV, IR, liquid chromatography-MS, and twodimensional heteronuclear multiple quantum coherence transfer spectroscopy nuclear magnetic resonance spectral data and named it as "amadannulen," a novel compound. Amadannulen also reported antibacterial activity against both Gram-positive and Gram-negative bacteria tested [9].

\section{Antitubercular activity}

Singh et al. reported that a labdane diterpene dialdehyde was first time isolated from the chloroform extract of rhizomes of $C$. amada. This compound exhibited antitubercular activity against Mycobacterium tuberculosis H37Rv strain in BACTEC-460 assay. It is the first report on isolation and ant mycobacterial activity of this dialdehyde from $C$. amada [10].

\section{ANGUSTIFOLIA}

C. angustifolia also known as Indian Arrowroot is an attractive ginger with stout underground rhizomes which lie dormant in winters. In early spring, the flowers are produced before the leaves. The shape and color of the bracts are very variable. The inflorescence lasts in full bloom on the plants for about 3 weeks and more. Good for cut flower use with a vase life of 10 days and more for fresh cut blooms. Leaves grow to about $2 \mathrm{ft}$ tall and die down in autumn. East Indian Arrowroot is found in the Himalayas, from Kumaon to NE India and SE Asia, at altitudes of 900-1210 m [11].

\section{Pharmacological activity}

Anti-ulcerogenic activity

Rajashekhara et al. showed that the starch of $C$. angustifolia showed a significant decrease in the volume, increase in the $\mathrm{pH}$, reduced the free acidity of gastric juice, and decreased the peptic activity. The studies were carried out in gastric-induced albino rats. From the above research article, it can be concluded that $C$. agustifolia has anti-ulcer activity [12].

\section{AROMATICA}

C. aromatica Salisb., mentioned as "Vanaharidra" in Ayurveda, belongs to the "ginger family" Zingiberaceae. It is a perennial herb with characteristic aromatic rhizomes used in many traditional systems of medicines in India, China, and other Southeast Asian countries. The rhizome of the plant is rich in alkaloids, flavonoids, curcuminoids, tannins, and terpenoids which are reported to be the reasons for its various pharmacological properties. The extraction of compounds in different solvents shows that the plant contains curdione, neocurdione, and germacrone as its major components. Extensive literature survey showed that the plant has anticancerous, antiobesity, antiacne, antitussive, antioxidant, anti-inflammatory, antidiabetic, and wound healing properties [13].

\section{Pharmacological activity \\ Wound healing activity}

The powdered rhizome of $C$. aromatica exhibited wound healing activity in rabbits. Studies also showed significant wound healing activity in excision wound models, conducted to assess the wound healing activity of topical application of $C$. aromatica rhizome extracts and its cream formulations [14].

\section{Anticancer activity}

Curcumin, a potential antioxidant extracted from C. aromatica, has been widely studied and showed anticarcinogenic properties in a wide variety of cell lines. A study was conducted to evaluate the anticancer effects of the aqueous extract of $C$. aromatica (AECA) and related molecular mechanisms of $C$. aromatica in human colon carcinoma LS174-T cell line with wild-type p53 used as a model cell. This study suggested that AECA might be effective as an antiproliferative herb for colon carcinoma [13,15-17].

\section{Larvicidal activity}

The rhizome extract and its volatile components of the plant are reported for their anti-larvicidal activity. Das et al. evaluated mustard (Brassica sp.) and coconut (Cocos sp.) oil-based rhizome extract oil against mosquitoes and reported protection in both the bases at all the tested concentrations $[13,18]$. The ethanolic extract of $C$. aromatica showed a protective effect against Armigeres subalbatus, Culex 
quinquefasciatus, and C. tritaeniorhynchus. Thus, the extract can be applied as an effective personal protection measure against mosquito bites. The rhizome extract is effective against Aedes togoi [19].

\section{Antioxidant activity}

The rhizome extracts of $C$. aromatica were found to be effective antioxidant agents. The sesquiterpenoids present in the volatile oil of C. aromatica functions as anti-inflammatory, antivirus, and antioxidant agent [20]. The methanol extract of essential oil from the leaves exhibited remarkable superoxide radical scavenging activities [21].

\section{CAESIA}

C. caesia (family Zingiberaceae) is a perennial herb. The plant is distributed throughout the tropical and subtropical regions of the world and is widely cultivated in Asian countries. In India, it is popularly known as "Kala Haldi." There are many reports on the pharmacological effects of Curcuma drugs such as their ability to express antitumor, antiinflammatory, antifungal, and immunological activities.

\section{Pharmacological activity}

Smooth muscle relaxant

C. caesia is widely used in India as both an anti-inflammatory and antiasthmatic in Ayurvedic medicine. However, there are no published pharmacological data on C. caesia on its potential antiasthmatic activity. Hydroalcoholic extract of $C$. caesia was tested for its relaxant effect in guinea pig trachea and also in the presence of various receptor antagonists and enzyme inhibitors, namely propranolol, 2,5-dideoxyadenosine, methylene blue, glibenclamide, N-nitro-Larginine, and chymotrypsin. Results suggested that the relaxant action mechanism of $C$. caesia extract may be inhibition of calcium release from intracellular calcium stores as well the calcium efflux from extracellular space. The present data may shed some light on the ethnomedical usage of $C$. caesia in asthma and other vascular disorders [22].

\section{Scavenging activity/antioxidant activity}

Karmakar et al. evaluated the methanol extract of $C$. caesia rhizome for some in vitro antioxidant studies as it is know that many diseases are associated with reactive oxygen species and reactive nitrogen species. Lipid peroxidation and total phenolic content were also measured by standard assay method. The extract showed significant antioxidant activities in a dose-dependent manner. From the above study it is concluded that the methanol extract of $C$. caesia rhizome is a potential source of natural antioxidant [23].

\section{LONGA}

Turmeric is a spice that has received much interest from both the medical/scientific worlds as well as from the culinary world. Turmeric is a rhizomatous herbaceous perennial plant $(C$. longa $)$ of the ginger family [24,25]. Curcumin (1,7-bis(4-hydroxy-3-methoxyphenyl)-1,6heptadiene-3,5-dione), also called diferuloylmethane, is the main natural polyphenol found in the rhizome of $C$. longa (turmeric) and in others Curcuma spp. $[24,26]$. C. longa has been traditionally used in Asian countries as a medical herb due to its antioxidant and antiinflammatory $[24,27]$. The plant grows to a height of $3-5 \mathrm{ft}$. It has oblong, pointed leaves and bears funnel-shaped yellow flowers, peeping out of large bracts. The rhizome is the portion of the plant used medicinally. It is usually boiled, cleaned, and dried, yielding a yellow powder [28].

\section{Chemical composition of turmeric (C. longa)}

Turmeric contains protein $(6.3 \%)$, fat $(5.1 \%)$, minerals $(3.5 \%)$, carbohydrates (69.4\%), and moisture (13.1\%). The essential oil $(5.8 \%)$ obtained by steam distillation of rhizomes has a-phellandrene $(1 \%)$, sabinene $(0.6 \%)$, cineol $(1 \%)$, borneol $(0.5 \%)$, zingiberene (25\%), and sesquiterpenes (53\%) [5]. Curcumin (diferuloylmethane) $(3-4 \%)$ is responsible for the yellow color and comprises curcumin I (94\%), curcumin II (6\%), and curcumin III (0.3\%) [6]. Demethoxy and bisdemethoxy derivatives of curcumin have also been isolated [7].
Curcumin was first isolated [8] in 1815, and its chemical structure was determined by Roughley and Whiting [9] in 1973. It has a melting point at $176-177^{\circ} \mathrm{C}$, forms a reddish-brown salt with alkali, and is soluble in ethanol, alkali, ketone, acetic acid, and chloroform [29].

\section{Pharmacological activity}

\section{Anticancer activity}

Kuttan et al. carried out anticancer activity on the rhizomes of turmeric and evaluated through in vitro studies using tissue culture methods and in vivo in mice using Dalton's lymphoma cells grown as ascites form. Turmeric extract inhibited the cell growth in Chinese Hamster Ovary cells at a concentration of $0.4 \mathrm{mg} / \mathrm{ml}$ and was cytotoxic to lymphocytes and Dalton's lymphoma cells at the same concentration. Cytotoxic effect was found within $30 \mathrm{~min}$ at room temperature $\left(30^{\circ} \mathrm{C}\right)$. The active constituent was found to be "curcumin" which showed cytotoxicity to lymphocytes and Dalton's lymphoma cells at a concentration of $4 \mu \mathrm{g} / \mathrm{ml}$ [30].

\section{Antimalarial activity}

Odugbemi et al. suggested in their review article the combinations of various herbal plants that have the potential to act against malarial parasites. The combination including Curcuma longa is (Ocimum gratissimum [leaves], Anacardium occidentale [foliage leaves], Lecaniodiscus cupanioides [foliage leaves], Curcuma longa [foliage leaves], Citrus aurantifolia [foliage leaves]) [31].

\section{Anticoagulant activity}

Hermann et al. stated that 1, 7-Bis(4-hydroxy-3-methoxyphenyl)-1,6-3, 5-dione (curcumin), p,p'-dihydroxydicinna-moylmethane, and p-hydroxycinnamoyl(feruloyl)methane were found to be the principles of $C$. longa with anticoagulative activity when recalcification time in male mice was measured [32].

Srivastava et al. stated that curcumin at doses between 25 and $100 \mathrm{mg} / \mathrm{kg}$ (i.p.) inhibits collagen and adrenaline-induces of platelet aggregation in in-vitro as well as in in-vivo but does not affect prostacyclin synthesis by rat thoracic aorta[33].

\section{PSEUDOMONTANA}

C. pseudomontana J. Graham belongs to the family Zingiberaceae, commonly known as Hill Turmeric. C. pseudomontana has small root stock, bearing small almond-like or subglobose tubers at the ends of the fibers (but no sessile tubers) and it is edible. Leaves are uniformly green, reaching $2 \mathrm{ft}$ or more long (including the petiole), 4-6' broad, lanceolate oblong acuminate, tapering to the base, petioles 8-15 in long [34]. C. pseudomontana is an extremely rare Zingiberaceae species found so far only in the Naikongchhari-forested area of Bandarban district in the southeastern hilly area of Bangladesh. In English, it is known as hill turmeric, while in Bangladesh, it is sometimes referred to as bon holud (wild turmeric) or pahariholud (hill turmeric) by the local people [35].

\section{Pharmacological activity \\ Antimicrobial activity}

All extracts of the rhizome of $C$. pseudomontana were screened in vitro for their antimicrobial activities against clinically isolated bacterial and fungal strains, such as S. aureus, Salmonella typhi, E. coli, and Aspergillus terreus. In result, it is found that methanolic extract showed $4 \mathrm{~mm}$ zone of inhibition against $S$. typhi, $6 \mathrm{~mm}$ against $S$. aureus, and $8 \mathrm{~mm}$ against E. coli. There were $2 \mathrm{~mm}$ zone of inhibition in acetone and $6 \mathrm{~mm}$ in methanol and aqueous against $A$. terreus. There was no zone of inhibition in chloroform against all the microorganisms and acetone as well as aqueous against $S$. typhi, S. aureus, and E. coli. Conducted by Begam et al., C. pseudomontana was proven to be effective [36]

\section{Antitubercular activity}

Rhizome extract exhibited significant antitubercular activity against M. tuberculosis H37 RV conducted by Hiremath and Kaliwal [37]. 


\section{Anticancer activity}

Different plant extract of $C$. pseudomontana contains certain types of active compounds; these active compounds show anticancer activity. These active compounds are extracted with appropriate solvent (organic/inorganic). Selection of solvent depends on the type of active compound conducted by Bisht et al. [38].

\section{XANTHORRHIZA}

C. xanthorrhiza Roxb. commonly known as temulawak or Javanese turmeric is one type of herbs derived from family Zingiberaceae. Xanthorrhizol (XNT) is a bisabolane-type sesquiterpenoid compound extracted from C. xanthorrhiza Roxb. [39]. XNT is the most active and abundant compound isolated from the essential oil of the rhizomes of C. xanthorrhizza Roxb. [40]. It is used in Southeast Asian countries for food and medicinal purposes. C. xanthorrhiza has been traditionally used to treat stomach disease, liver disorder, constipation, dysentery, diarrhea, children's fever, and hemorrhoids [41]. Biological properties of the extracts and essential oils from $C$. xanthorrhiza have been studied by many researchers. They include hepatoprotective and antinociceptive activities [42]. The dried rhizomes of C. xanthorrhiza are grounded and soaked in $95 \%$ ethanol for 2 days at room temperature [43]. This plant originated from Indonesia, more specifically from Java island, of which it spreads to several places in the biogeographical region, Malaysia [44]. Rhizome of $C$. xanthorrhiza contains two characteristic constituent, i. e., curcuminoids (curcumin and desmethoxycurcumin) and XNT [45]. XNT is a bisabolane-type sesquiterpenoid compound. It has been well established to possess a variety of biological activities such as anticancer, antimicrobial, anti-inflammatory, antioxidant, antihyperglycemic, antihypertensive, antiplatelet, nephroprotective, hepatoprotective, estrogenic, and antiestrogenic effects [39]. Some studies suggest that C. xanthorrhiza also has the potential to cause herb-drug interaction with drugs that are primarily metabolized by UDP-glucuronosyl transferase and glutathione S-transferase enzymes [46].

\section{Pharmacological activity}

\section{Cytotoxicity activity}

The ethyl acetate fractions of samples $C$. xanthorrhiza exhibited the highest cytotoxic activities, and all samples in cytotoxic activities were showed not significantly with the others in $p \leq 0.05$. The cytotoxicity of the ethyl acetate fractions in different sample rhizomes of C. zanthorrhiza was evaluated using the brine shrimp lethality test for potency in preliminary screening for cytotoxins as anticancer [47].

\section{Hepatoprotective activity}

C. xanthorrhiza has been used for centuries in the traditional system of medicine to treat several diseases such as hepatitis, liver complaints, and diabetes. It has been consumed as food supplement and "jamu" as a remedy for hepatitis. Hence, it leads in research for the activity on the liver. Ismail et al. carried out the research on antioxidant activity of the standardized $C$. xanthorrhiza fractions using in vitro assays. Hepatoprotective assay was conducted against carbon tetrachloride-induced hepatic damage in rats at doses of 125,250 , and $500 \mathrm{mg} / \mathrm{kg}$ of hexane fraction. Highest antioxidant activity was found in hexane fraction. In the case of hepatoprotective activity, C. xanthorrhiza hexane fraction showed significant improvement in terms of a biochemical liver function, antioxidative liver enzymes, and lipid peroxidation activity [48].

\section{Anti-inflammatory activity (ulcerative colitis)}

Chun et al. carried out the research on $C$. xanthorrhiza, and the findings suggest that $C$. xanthorrhoea is an effective inhibitor of DSSinduced ulcerative colitis in mice. The anti-inflammatory effects of C. xanthorrhiza were associated with attenuated tissue injury, recruitment of neutrophils, and suppression of inflammation-related gene expression. The researchers conclude that $C$. xanthorrhiza is a relatively edible and non-toxic natural plant material that appears to be a beneficial gut-related dietary supplement and that its use may provide an alternative approach to modulating inflammation [49].

\section{Antimicrobial activity}

XNT is considered active against a variety of pathogenic microorganisms. Antimicrobial effects of XNT included antibacterial [50-52]. XNT also strongly inhibited Gram-positive bacteria $S$. aureus, methicillin-resistant S. aureus, Gram-negative bacteria E. coli [53], and acne-causing bacteria Propionibacterium acnes [54].

\section{ZEDOARIA}

C. zedoaria Rosc. is a commonly available plant in the dava-bazaar as Kachore is a potential antimicrobial agent as it shows significant activity against common bacterial and fungal pathogen [55]. It also is very common ingredient of body deodorant (ubtans), hair oils, and face washes [56,57]. C. zedoaria is a traditionally used medicine which is described in ancient Ayurveda literature for ailments such as arthritis, colic, cough, asthma, diarrhea, dysentery, rheumatism, and skin disease $[58,59]$. According to the traditional Chinese medicine, $C$. zedoaria rhizomes contain several specific sesquiterpenes that are effective against flatulent colic, debility of the digestive organs, amenorrhea, hepatocirrhosis, cancer, oxidation, and human blood aggregation [60-65].

\section{Pharmacological activity}

\section{Antitumor activity}

The compound isolated from the rhizomes of $C$. zedoaria, characterized as isocurcumenol by the MS and IR spectra, significantly inhibited the cell proliferation in human lung, leukemia, nasopharyngeal carcinoma, and murine lymphoma cells.

The in vivo studies suggested the non-toxic nature of the compound at low doses and its antitumor effects in the ascetic tumor development comparable to the standard drug used to treat lymphoma and cyclophosphamide. The present study highlights the antitumor potential of isocurcumenol isolated from $C$. zedoaria to be exploited further to be developed as a good antitumor agent [66].

\section{Antimicrobial and antibacterial activity}

Ethanolic extract of $C$. zedoaria was tested against various pathogenic bacteria and fungi. The results obtained are based on antibacterial and antifungal activity as shown by essential oil of $C$. zedoaria on various organisms. Ethanolic extracts showed excellent activity against S. aureus and Trichophyton mentagrophytes [58].

\section{Anticancer activity}

In the previous study, a crude ethanolic extract of C. zedoaria showed an inhibitory effect against OVCAR-3 cells (human ovarian cancer) $[60,67,68]$.

\section{Anti-amoebic activity}

Alcoholic extract of rhizome of $C$. zedoaria was able to inhibit the growth of Endamoeba histolytic at a concentration of $1-10 \mathrm{mg} / \mathrm{ml}$ [69].

\section{Hepatoprotective activity}

Hepatoprotective sesquiterpenes were isolated from the aqueous acetone extract of the rhizome of $C$. zedoaria. Principal sesquiterpenes, furanodiene, germacrone, curdione [70], neocurdione [71], curcumenol, isocurcumenol, aerugidiol, zedoarondiol, curcumenone, and curcumin were found to show the potent protective effect on D-galactosamine (DGalN)/lipopolysaccharide-induced acute liver injury in mice [72].

\section{Antivenom activity}

Aqueous extract of $C$. zedoaria was investigated for inhibitory activity by binding of anticobra venom antibody to antigen of cobra venom using the 96-well plate enzyme-linked immunosorbent assay method. In this study, the extract was allowed to react with immobilized venom before the addition of antivenom antibody. The extract of $C$. zedoaria showed clear inhibitory activity. It was found that the extract targeted 
neurotoxin and protein-degrading enzyme present in venom, thus suggesting the use of aqueous extract as antivenom [73].

\section{CONCLUSION}

Curcuma species are very promising medicinal plants with great pharmacological impact. The above review article gives an insight on the potential of different Curcuma species regarding their medicinal value. Various studies demonstrated that these Curcuma species possess anticancer, antimicrobial, antitubercular, antitumor, antibacterial, wound healing activity, and fungicidal. Review of the literature concluded that the curcuma species have great potential in innovative research in future and to be considered as a useful herbal medicinal plant

\section{ACKNOWLEDGMENT}

We are grateful to our Principal Dr. (Mrs) Sudha Rathod, Prof. Imtiyaz Ansari, and Prof. Dr. Sayyed Mateen for their patience and guidance and support as well as to Pharmacology department, Oriental College of Pharmacy, Navi Mumbai.

\section{AUTHOURS' CONTRIBUTION}

We declare that this work was done by the authors named in the article, and all liabilities pertaining to claims relating to the content of this article will be borne by the authors. Miss Farha Khan collected the data and analyzed the data. Dr (Mrs) Vanita Kanase proofread the whole manuscript and suggested the necessary changes and help in designing the manuscript.

\section{CONFLICTS OF INTEREST}

The authors declare that there are no conflicts of interest regarding the publication of this paper.

\section{REFERENCES}

1. Prasad S, Aggarwal BB. Turmeric, the golden spice: From traditional medicine to modern medicine. In: Benzie IF, Wachtel-Galor S, editors. Herbal Medicine: Biomolecular and Clinical Aspects. $2^{\text {nd }}$ ed. Ch. 13. Boca Raton (FL): CRC Press/Taylor \& Francis; 2011

2. Amit S. Promising Curcuma species suitable for hill regions towards maintaining biodiversity. J Pharmacog Phytochem 2017;6:726-31.

3. Fayaz A. Encyclopedia of Tropical Plants-Identification and Cultivation of Over 3,000 Tropical Plants. Kuwait: Firefly Books Ltd.; 2014.

4. Tropical Plants Database, Ken Fern. Available from: http://www. tropical.theferns.info. [Last accessed on 2018 Jun 25].

5. Kamazeri TS. Antimicrobial activity and essential oils of Curcuma aeruginosa, Curcuma mangga, and Zingiber cassumunar from Malaysia. Asian Pac J Trop Med 2012;5:202-9.

6. Asih T. Investigation of anti-inflammatory activities of Curcuma aeruginosa Roxb. in experimental animals. Int J Sci Res Publ 2015;15:191.

7. Policegoudra RS. Mango ginger (Curcuma amada Roxb.)--a promising spice for phytochemicals and biological activities. J Biosci 2011;36:739-48.

8. Mujumdar AM, Naik DG, Dandge CN, Puntambekar HM. Antiinflammatory activity of Curcuma amada Roxb. in albino rats Indian J Pharmacol 2000;32:375-7.

9. Policegoudra RS, Abiraj K, Channe Gowda D, Aradhya SM. Isolation and characterization of antioxidant and antibacterial compound from mango ginger (Curcuma amada roxb.) rhizome. J Chromatogr B Analyt Technol Biomed Life Sci 2007;852:40-8.

10. Singh S, Kumar JK, Saikia D, Shanker K, Thakur JP, Negi AS, et al. A bioactive labdane diterpenoid from Curcuma amada and its semisynthetic analogues as antitubercular agents. Eur J Med Chem 2010;45:4379-82.

11. Available from: http://www.flowersofindia.net/catalog/slides/East $\% 20$ Indian\%20Arrowroot.html.

12. Rajashekhara N, Ashok BK, Sharma PP, Ravishankar B. The evaluation of anti-ulcerogenic effect of rhizome starch of two source plants of Tugaksheeree (Curcuma angustifolia Roxb. and Maranta arundinacea Linn.) on pyloric ligated rats. Ayu 2014;35:191-7.

13. Anoop K. Curcuma aromatica salisb: A multifaceted spice. Int J
Phytopharm Res 2015;6:10-5.

14. Kumar A, Chomwal R, Kumar P, Renu S. Anti-inflammatory and wound healing activity of Curcuma aromatica Salisb extract and its formulation. J Chem Pharm Res 2009;1:304-10.

15. Jee SH, Shen SC, Tseng CR, Chiu HC, Kuo ML. Curcumin induces a p53-dependent apoptosis in human basal cell carcinoma cells. J Invest Dermatol 1998;111:656-66.

16. Ruby AJ, Kuttan G, Babu KD, Rajasekharan KN, Kuttan R. Antitumour and antioxidant activity of natural curcuminoids. Cancer Lett 1995;94:79-83.

17. Deng SG, Wu ZF, Li WY, Yang ZG, Chang G, Meng FZ, et al. Safety of Curcuma aromatica oil gelatin microspheres administered via hepatic artery. World J Gastroenterol 2004;10:2637-42.

18. Das NG, Nath DR, Baruah I, Talukdar PK, Das SC. Field evaluation of herbal mosquito repellents. J Commun Dis 1999;31:241-5.

19. Pitasawat B, Choochote W, Tuetun B, Tippawangkosol P, Kanjanapothi $\mathrm{D}$, Jitpakdi A, et al. Repellency of aromatic turmeric Curcuma aromatica under laboratory and field conditions. J Vector Ecol 2003;28:234-40.

20. Jiang Y, Li ZS, Jiang FS, Deng X, Yao CS, Nie G. Effects of different ingredients of zedoary on gene expression of HSC-T6 cells. World J Gastroenterol 2005;11:6780-6.

21. Al-Reza SM, Rahman A, Sattar MA, Rahman MO, Fida HM. Essential oil composition and antioxidant activities of Curcuma aromatica Salisb. Food Chem Toxicol 2010;48:1757.

22. Arulmozhi DK, Sridhar N, Veeranjaneyulu A, Arora SK. Preliminary mechanistic studies on the smooth muscle relaxant effect of hydroalcoholic extract of Curcuma caesia. J Herb Pharmacother 2006;6:117-24.

23. Karmakar I, Dolai N, Saha P, Sarkar N, Bala A, Haldar PK. Scavenging activity of Curcuma caesia rhizome against reactive oxygen and nitrogen species. Orient Pharm Exp Med 2011;11:221-8.

24. Hewlings SJ, Kalman DS. Curcumin: A review of Its' effects on human health. Foods 2017;6:92.

25. Priyadarsini KI. The chemistry of curcumin: From extraction to therapeutic agent. Molecules 2014;19:20091-112.

26. Aggarwal BB, Kumar A, Bharti AC. Anticancer potential of curcumin: Preclinical and clinical studies. Anticancer Res 2003;23:363-98.

27. Lestari ML, Indrayanto G. Curcumin. Profiles drug subst. Excip Relat Methodol 2014;39:113-204.

28. Flowers of India. Available from: https://www.flowersofindia.net/ catalog/slides/Turmeric.html

29. Ashraf K, Sultan S. A comprehensive review on Curcuma longa Linn. Phytochemical, pharmacological, and molecular study. Int J Green Pharm 2017;11:S672.

30. Kuttan R, Bhanumathy P, Nirmala K, George MC. Potential anticancer activity of turmeric (Curcuma longa). Cancer Lett 1985;29:197-202.

31. Odugbemi TO, Akinsulire OR, Aibinu IE, Fabeku PO. Medicinal plants useful for malaria therapy in Okeigbo, Ondo state, southwest Nigeria. Afr J Tradit Complement Altern Med 2006;4:191-8.

32. Ammon HP, Wahl MA. Pharmacology of Curcuma longa. Planta Med 1991;57:1-7.

33. Srivastava R, Dikshit M, Srimal RC, Dhawan BN. Anti-thrombotic effect of Curcumin. Thromb Res 1985;40:413-7.

34. Gurusiddesh H. Pharmacognostic evaluation of rhizome of Curcuma pseudomontana j. Graham. Int J Pharm BioSci 2014;5:242-50.

35. Rashed R, Shahriad S, Mohammed R. Curcuma pseudomontana-a rare Zingiberaceae species plant of Bangladesh and its medicinal uses. Asian J Pharm 2018:1:31-2.

36. Begam SR, Karthikeyan S, Arumugam M, John SA. Antibacterial activity of Curcuma psedomontana with special reference to multi drug resistant pathogens. Int J Pharmacol Scree Methods 2014;4:127-30.

37. Hiremath GB, Kaliwal BB. Anti-tubercular activity of the rhizome of Curcuma pseudomontana J. Graham. Int J Pharm Health Care Res 2013;7:178-83.

38. Bisht VS, Kandwal S, Kanan D, Som D. Anticancerous and antiproliferative/cytotoxic activity of Curcuma pseudomontana (hill turmeric) collected from the sub Himalayan region of Uttrakhand, India. Asian J Plant Sci Res 2014;4:25-31.

39. Oon SF, Nallappan M, Tee TT, Shohaimi S, Kassim NK, Sa'ariwijaya MS, et al. Xanthorrhizol: A review of its pharmacological activities and anticancer properties. Cancer Cell Int 2015;15:100.

40. Jantan I, Saputri FC, Qaisar MN, Buang F. Correlation between chemical composition of Curcuma domestica and Curcuma xanthorrhiza and their antioxidant effect on human low-density lipoprotein oxidation. Evid Based Complement Alternat Med 2012;2012:438356.

41. Sukandar EY, Kurniati NF, Anggadiredja K, Kamil A. In vitro antibacterial activity of Kaempferia pandurata roxb. and Curcuma 
xanthorrhiza roxb. Extracts in combination with certain antibiotics against MSSA and mrsa. Int J Pharm Pharm Sci 2016;8:108-11.

42. Hartiwi D, Syah YM, Lia D. Antibacterial Curcuma xanthorrhiza extract and fractions. J Math Fundam Sci 2014;46:224-34.

43. Kim MB, Kim C, Song Y, Hwang JK. Antihyperglycemic and antiinflammatory effects of standardized Curcuma xanthorrhiza Roxb. Extract and its active compound xanthorrhizol in high-fat diet-induced obese mice. Evid Based Complement Alternat Med 2014;2014:205915.

44. Sukardiman, Suharjono, Oktaviyanti ND. Immunohistochemical Study of Curcuma Xantorrhiza Roxb. and Morinda citirifolia L. Ethanolic extract granules combination in high fat diet induced hyperlipidemia rats. Int J Pharm Pharm Sci 2014;6:142-5.

45. Wardini TH, Prakoso B, Jansen PC. Curcuma zanthorhizza Roxb. Fl Ind1820;1:25.

46. Salleh NA, Ismail S, Ab Halim MR. Effects of Curcuma xanthorrhiza extracts and their constituents on phase II drug-metabolizing enzymes activity. Pharmacognosy Res 2016;8:309-15.

47. Nurcholis W. Xanthorrhizol contents,-glucosidase inhibition, and cytotoxic activities in ethyl acetate fraction of Curcuma zanthorhizza accessions from Indonesia. Braz J Pharmacog 2017;28:44-9.

48. Devaraj S, Ismail S, Ramanathan S, Yam MF. Investigation of antioxidant and hepatoprotective activity of standardized Curcuma xanthorrhiza rhizome in carbon tetrachloride-induced hepatic damaged rats. Sci World J 2014;2014:353128.

49. Chun HS. Standardized ethanolic extract of the rhizome of Curcuma xanthorrhiza prevents murine ulcerative colitis by regulation of inflammation. J Funct Foods 2017;30:282-9.

50. Hwang JK, Shim JS, Baek NI, Pyun YR. Xanthorrhizol: A potential antibacterial agent from Curcuma xanthorrhiza agains Streptococcus mutans. Planta Med 2000;66:196-7.

51. Hwang JK, Shim JS, Pyun YR. Antibacterial activity of xanthorrhizol from Curcuma xanthorrhiza against oral pathogens. Fitoterapia 2000;71:321-23.

52. Rukayadi Y, Hwang JK. In vitro activity of xanthorrhizol against Streptococcus mutans biofilms. Lett Appl Microbiol 2005;42:400-4.

53. Mustaffa F, Indurkar J, Ismail S, Shah M, Mansor SM. An antimicrobial compound isolated from Cinnamomum iners leaves with activity against methicillin-resistant Staphylococcus aureus. Molecules 2011;16:3037-47.

54. Batubara I, Julita I, Darusman LK, Muddathir AM, Mitsunaga T. Flower bracts of temulawak (Curcuma xanthorrhiza) for skin care: Anti-acne and whitening agents. Procedia Chem 2015;14:216-24.

55. Batubara I, Julita I, Darusman LK, Muddathir AM, Mitsunaga T. Flower bracts of temulawak (Curcuma xanthorrhiza) for skin care: antiacne and whitening agents. Procedia Chem 2015;14:216-24

56. Kirtikar KR, Basu BD. Indian Medicinal Plants. $2^{\text {nd }}$ ed., Vol. IV. Allahabad: Lalit Mohan Basu, Reprinted 1975. p. 2426-7, 2430-431.

57. Bhishagratna KL. Sushrut Samhita (English Translation). Varanasi: Chowkhamba Press; 1996.
58. Chachad DP, Talpade MB, Jagdale SP. Antimicrobial activity of rhizomes of Curcuma zedoaria Rosc. Int J Sci Res (IJSR) 2016;5:938-40.

59. Prajapati ND, Kumar U. Agro's Dictionary of Medicinal Plants. $1^{\text {st }}$ ed. India: Agrobiosis; 2003.

60. Carvalho FR, Vassão RC, Nicoletti MA, Maria DA. Effect of Curcuma zedoaria crude extract against tumor progression and immunomodulation. Afr J Biotechnol 2016;10:11676-81.

61. Yoshioka T, Fujii E, Endo M, Wada K, Tokunaga Y, Shiba N, et al. Antiinflamatory potency of dehydrocurdione, a zedoary-derived sesquiterpene. Inflamm Res 1998;47:476-81.

62. Jang MK, Sohn DH, Ryu JH. A curcuminoid and sesquiterpenes as inhibitors of macrophage TNF- $\alpha$ release from Curcuma zedoaria. Planta Med 2001;67:550-2

63. Kim KI, Kim JW, Hong BS, Shin DH, Cho HY, Kim HK, et al. Antitumor, genotoxicity and anticlastogenic activities of polysaccharide from Curcuma zedoaria. Mol Cells 2000;10:392-8.

64. Kim KI, Shin KS, Jun WJ, Hong BS, Shin DH, Cho HY, et al. Effects of polysaccharides from rhizomes of Curcuma zedoaria on macrophage functions. Biosci Biotechnol Biochem 2001;65:2369-77.

65. Lee H, Lin JY. Antimutagenic activity of extracts from anticancer drugs in Chinese medicine. Mutat Res 1988;204:229-34.

66. Lakshmi S, Padmaja G, Remani P. Antitumour effects of isocurcumenol isolated from Curcuma zedoaria rhizomes on human and murine cancer cells. Int J Med Chem 2011;2011:Article ID 253962, 13 Pages.

67. Syu WJ, Shen CC, Don MJ, Ou JC, Lee GH, Sun CM. Cytotoxicity of curcuminoids and some novel compounds from Curcuma zedoaria. J Nat Prod 1998;61:1531-4.

68. Anuchapreeda S, Leechanachai P, Smith MM, Ambudkar SV, Limtrakul P. Modulation of P-glycoprotein expression and function by curcumin in multidrug-resistant human KB cells. Biochem Pharmacol 2002;64:573-82

69. Raghuveer GP, Ali M, Eranna D, Setty R. Evaluation of anti-ulcer effect of root of Curcuma zedoaria in rats. Indian J Trad Knowl 2004:2:375-7.

70. Uechi S, Ishimine Y, Hongo F. Antibacterial activity of essential oil derived from Curcuma sp. (Zingiberaceae) against foodborne pathogenic bacteria and its heat-stability. Sci Bull Faculty Agric 2000;47:129-36

71. Bugno A, Aparecida M, Adriana N, Almodóvar B, Tatiana C. Antimicrobial efficacy of Curcuma zedoaria extract as assessed by linear regression compared with commercial mouthrinses. Braz J Microbiol 2007;38:440-5.

72. Matsuda H, Ninomiya K, Morikawa T, Yoshikawa M. Inhibitory effect and action mechanism of sesquiterpenes from Zedoariae rhizoma on D-galactosamine/lipopolysaccharide-induced liver injury. Bioorg Med Chem Lett 1998;8:339-44

73. Daduang S, Sattayasai N, Sattayasai J, Tophrom P, Thammathaworn A, Chaveerach A, et al. Screening of plants containing naja Naja siamensis cobra venom inhibitory activity using modified ELISA technique. Anal Biochem 2005;341:316-25. 